\title{
Television and the popular: viewing from the British perspective
}

Article

Published Version

Bignell, J. (2010) Television and the popular: viewing from the British perspective. Journal of Literary Theory, 4 (2). pp. 181 198. ISSN 1862-5290 doi:

https://doi.org/10.1515/JLT.2010.012 Available at https://centaur.reading.ac.uk/18657/

It is advisable to refer to the publisher's version if you intend to cite from the work. See Guidance on citing.

To link to this article DOI: http://dx.doi.org/10.1515/JLT.2010.012

Publisher: De Gruyter

All outputs in CentAUR are protected by Intellectual Property Rights law, including copyright law. Copyright and IPR is retained by the creators or other copyright holders. Terms and conditions for use of this material are defined in the End User Agreement.

\section{www.reading.ac.uk/centaur}

\section{CentAUR}

Central Archive at the University of Reading

Reading's research outputs online 


\title{
JONATHAN BIGNELL
}

\section{Television and the Popular}

\author{
Viewing from the British Perspective
}

After a brief discussion of television industry definitions of 'popular', this article discusses the variant meanings of the popular in academic approaches to television. While not structured chronologically, the article aims to demonstrate that, across the late twentieth and early twenty-first centuries, critical approaches to television have constituted their object of study in different ways, leading to different evaluative schemas and considerable conceptual and terminological confusion. The article focuses mainly on British programmes and critical writing, but places British television culture in a broader international context. It focuses mainly on television fiction, but also includes some discussion of factual entertainment programming since this has been culturally prominent in recent times. The organisation of this article reflects the range of dominant methodologies in the field of Television Studies in the UK, which encompass the analytical study of television programmes as texts, the television industry as an institution along with its production practices and organisation, the role of television in contemporary culture, the study of audiences, and histories of television that emphasise one or more of those aspects of the medium's development. It is a recurrent motif in the theory and criticism of television that the medium is in a state of change so significant that previous critical paradigms need to be revised and new ones introduced (Brunsdon 2008).

Historically, the study of television emerged out of the changing forms taken by the larger field of media education. The premise that underpins media education is that academic studies should engage with everyday media experiences that are understood as an aspect of the popular culture of modernity. Foundational discourses in television and media studies encouraged the questioning of media use by means of the analysis of media products, media institutions and media technologies. The work of the literary and cultural critic Raymond Williams (1974) was crucial in establishing this breadth in the field, as a result of his interest in evaluative and discriminating critical discourse that would address television as an aspect of a dynamic cultural formation. In Europe, media education is often referred to as media literacy and it was in the United Kingdom that the idea was first put into practice in the context of school and university teaching. Key issues that structure this curric- 
ulum include the patterns of ownership of media organizations, where the national and global holdings of corporations such as News Corporation, Disney or Time Warner are assessed in terms of the concentration of media power in the hands of a few main players. The laws and regulations of media industries are also studied, in relation to censorship, bias, and assumptions about their influence. In addressing specific media texts like TV programmes, films or magazine advertisements, media education asks what audience the text is addressed to, and how the conventions of a certain genre or form are used to target an audience. The study of media audiences is interested in how different groups of viewers or readers interpret media content in different ways according to (for example) age, sex, gender or economic status.

Media education began in the 1930s on the assumption that mass media had deleterious effects on society, and that educating citizens about how media products are made would help to protect them from their impact. Television, beginning its history as a medium at about the same time, has long been regarded as a medium that has a special relationship with its viewers' everyday lives. Television's virtual ubiquity thus means that the scholarly study of television aims to estrange familiar programmes, and to attain critical distance from the quotidian and taken for granted. By the 1960s the emphasis moved to offering media education as a tool-kit that would enable ordinary people to originate their own media culture (in local television stations, or small-scale print publications), but in the UK financial support for such ramateur s television was never significant. In the 1970s and 1980s, theoretical developments in academic media studies, such as semiotics, led media education to focus on deconstructing media representations to reveal their hidden ideological assumptions, especially about gender. Most recently, scholars in the field have become interested in audiences, conducting studies of individual media users or audience groups, to provide a more finely-textured understanding of how and why television and other media are used in the context of ordinary life. So the key conceptual move to identify here is the placing of television among a larger media ensemble whose critique is recognized as part of the project of understanding modernity.

The role of the academic discipline of Television Studies in informing the production of television has always been peripheral, and in Britain at least, the field's focus in the 1960s and 1970s on making distinctions between progressive or conservative kinds of television, and highly theoretical arguments about form and meaning, had no real effect on writers and production staff in the business of making popular television. In response to a crisis of its own agency as an intervention into television culture, academic work paid increasing attention to the agency of viewers as active and resistant users of television, rather than as passive receivers. The crucial role of scheduling, and the transmission of programmes on one channel rather than another, contributed to the insight that the schedule produces interactions between programmes that are not determined by the expectations that a form or genre sets up for an individual programme. Formative work on this by Raymond 
Williams (1974) and John Ellis (1982) addressed the flow of programmes in the television schedule, and iflow quickly took on the status of a key term for subsequent theorisation. The analysis of flow refers both to the concatenation of programmes in a temporal sequence but also to the viewer's experience of composing his or her own television text from the segments that are viewed. Thus, thinking about popular television came to mean considering popular modes of viewing, as well as the programmes included in that viewing experience (Gripsrud 1997). Work on the agency and activity of the television viewer was an important attempt to capture some of the attractions of organic and resistant popular culture, and this was especially true of feminist studies that focused on the active use of television by women viewers (e.g., Brunsdon/D'Acci/Spigel 1997; Brunsdon 2000). While it was frustrating that academic television studies failed to impact on the cultural production that it had learned to critique, the development of sophisticated methodologies of detailed audio-visual analysis and the recognition of the dynamic complexity of viewers' interpretative activity was some compensation.

\section{The Popular and the National}

In focusing on semiotics, narrative structures and viewers' decoding of programmes, British academic discourses about popular television were very distinct from the discourses of the television industry. Television institutions measure what is popular by means of ratings or audience share. Ratings measure the total number of viewers watching a programme at a specified time, while the audience share is the proportion of the total number of people watching who have chosen to view a specified programme, rather than another being broadcast at the same moment. Television channels need to sustain substantial audiences in order to generate advertising revenue, since audience size and composition determine broadcasters' level of charges to advertisers. In the case of broadcasters funded by the state or by some other non-commercial means (such as the BBC's licence fee in the UK), healthy ratings and audience shares are required to justify the institution's claim for its funding. Individual television programmes occupy their schedule position by virtue of their success in attracting either an audience of significant size or an audience composed of valuable consumers. Popularity therefore, in this commercial sense, can refer either to sheer viewer numbers, or to a broadcaster's performance relative to its competitors.

However, there was no need for academics to promote a liberal alternative to the industry's quantitative and utilitarian criteria for popularity, because a very powerful liberal discourse already underpinned television organization and output. In the UK and in most West European nations, a concept of Public Service Broadcasting had enormous impact on how the popular was conceived. In the early institutionalisation of broadcasting in Britain in the 1920s, the requirement for radio (and 
later television) to be spopular referred to a notion of reflecting society to itself, constituting a public sphere of debate and engagement, and supplying a diverse range of freely-available cultural goods. Commercial broadcasters argued that the purpose of television is to offer whatever programmes the market wants, and thus primarily to offer entertainment. Popular television, in this conception, is the most-watched programmes. But the alternative and still powerful discourse regards television as a public service, which should reflect the whole of society and enhance its quality of citizenship. The BBC's guidelines for producers, for example, still state that: »The BBC has a responsibility to serve all sections of society in the United Kingdom. Its domestic services should aim to reflect and represent the composition of the nation « (BBC 2003, 89). Popular television, in this dominant conception, may still be the most-watched entertainment programmes but these must meet a threshold of quality and be part of a broader mix of provision. Public Service is thus an attitude and not a genre of programme, so it includes high-budget and aesthetically demanding work, but it also refers to the range of popular formats and genres, such as sitcom, sport and soap opera, that contribute to offering diverse kinds of form, topic, and mode of audience engagement. British academic discourses had the luxury of not needing to argue for this progressive television policy, and could devote their attention to particular dysfunctional aspects of the national television landscape.

One of the aspects of British television that was felt to need critique was popular light entertainment. As a medium predominantly experienced in the home, television both adopted and also transformed earlier forms of popular culture. Light entertainment television negotiates between a here and sthere of home and public spaces of entertainment, between ordinariness and spectacle, between ıusı and 'them . Thus for Richard Dyer (1973) for example, it co-opted and tamed working class culture. The star performers, the avuncular host, and the >ordinary` members of the public on stage both announce television's domestic familiarity and ordinariness, and also present television as a means of access to a spectacular world of celebrity. The effect, Dyer argued, is to frame the programme as a mediating format between earlier forms of popular entertainment such as vaudeville or music hall, and a broadcast designed for bourgeois domestic and private consumption. Public culture is signified by real or apparent liveness, an auditorium setting and a mix of types of content such as musical performance, interview, quiz or contest segments. On the other hand, domesticity is signified by the placement of the programme within the routines of a schedule designed to match the rhythms of domestic life (mealtimes, work versus leisure time, etc), modes of address that assume a home audience, and the use of multi-camera shooting techniques to edit the material into an event for television rather than a relayed performance. In this argument, popular programmes such as Strictly Come Dancing (known outside the UK as Dancing with the Stars) or Pop Idol present a border zone between the public world of celebrity and the private sphere of television viewership, with a deterrent 
relationship to popular culture; they publicize and privatize it, allude to it but transform it, and they celebrate yet sanitize it.

The example of Dancing with the Stars draws attention to the fact that popularity has regional, national and transnational aspects, and is thus implicated in the concept of globalization (Barker 1999). Critical discourse has recognized that television is transnational but takes nationally specific forms, and while British television draws primarily on programmes by British programme-makers, consciousness of national identity in and through television is also constituted against imported programmes and imported formats. Caricatures of US television in the UK, and also in continental Europe and beyond, have lent force to an assumption that television as a medium was added-on to a pre-existing national culture and has undermined the family, encouraged audience passivity, smuggled American values into broadcasting, and displaced an organic working-class culture. The immediate success of the ITV commercial channel in Britain from 1955 onwards provided ready examples for these pessimistic arguments, and it is significant that it is examples of the noncommercially funded BBC programmes and not commercial ITV ones that are most readily used in the UK and also abroad to praise the achievements of British television. Television has always been regarded with suspicion, as a medium that might be replacing one version of the popular , namely a valued national popular culture, with another. While the trading of programme ideas and formal components (the ingredients of a television format) is not limited by language, any conception of national domestic broadcasting has to deal with the belief that television is doomed to eventual colonisation and subservience to US programme formats, imports and funding models. What is at issue is the degree of determinism assigned in analytical discourse to the kinds of institutions which make and broadcast programmes, and the conclusions which can be drawn from television ownership, organization and geographical distribution.

For these reasons, a tradition of institutional and policy analysis has developed to assess inequalities in production funding, and different roles of domestic and imported programming in national television cultures. It has been argued that "world patterns of communication flow, both in density and in direction, mirror the system of domination in the economic and political order " (Sinclair et al. 1999, 173). Globalization theses proposed by Herbert Schiller (1969; 1976), for example, argued that the globalization of communication in the second half of the twentieth century was determined by the commercial interests of US corporations, working in parallel with political and military interests. This discourse connects cultural imperialism with the dynamics of colonialism, arguing that the colonial empires of Britain or France have been replaced by commercial empires. Traditional local cultures are said to be eroded by dependencies on media products and their attendant ideologies deriving from the United States, with the effect of globalizing popular culture across regions and populations which become constrained to adapt to its logics and desires. This cultural imperialism thesis, developed in the $1950 \mathrm{~s}$ 
and 1960s, pays scant regard to local and national specificities in media organization or consumption, nor to regional flows of media products. Academic analysis has therefore assessed the significance of regional structures and institutions to transnational conceptions of 'the popular (Bignell/Fickers 2008), such as The European Broadcasting Union (EBU), the Eurovision and Euronews networks, and the EU's trade facilitation body the European Audiovisual Observatory. The reason that such institutions are perceived to be required is primarily the influence of US popular television in Europe.

The critical discourses of television study have negotiated a complex understanding of American programmes. The most popular television programme in the world in 2005 was the American police drama series CSI: Miami (Eden 2006), and the list of most viewed programmes around the world included the US series Lost, Desperate Housewives, The Simpsons, CSI Crime Scene Investigation and Without a Trace. But for British and other European theorists, what is evident here is not the teleological progress of US media hegemony, but the unevenness of the impact of different genres of US television, and their contestation in specific contexts: "the impact of Anglo-American television in a global context may be understood as the creation of a layout of western capitalist modernity which overlays, but does not necessarily obliterate, pre-existing cultural forms« (Barker 1999, 42). Research by de Bens and de Smaele (2001) tracing the origin of films and series on 36 public and commercial channels from six European countries in 1997 confirmed the dominance of American drama and the limited distribution of European drama, despite the efforts of the European Union to combat these tendencies by quotas and subsidies. Public channels broadcast a wider range of national, nonnational European and American drama, with domestic drama series predominating over American series in prime-time on both public and commercial channels. De Bens and de Smaele found that European drama was constrained by considerations of language and cultural proximity in ways that American drama was not. However, globalization generates or at least defines its own other, namely localization. Localization in television is relational, and relative to globalizing processes, and this can be seen in the presence of localization initially as an other to national broadcasting (the creation of regional television channels and programmes in Britain and Spain, for example, for Welsh and Catalan audiences respectively) and then to transnational and global television developments. Indeed, for global television institutions, whether commercial corporations or regulatory bodies, negotiations between rather than the overcoming of global, national, regional and local television have been evident in recent decades. Research on popular television presents it as a site of contestation between both homogenising and differentiating forces. 


\section{The People on Screen}

The popular also carries the meaning of production by sthe peoples themselves, but this notion of an organic culture conflicts with the industrial, institutional and technological facts of television. There has never been a significant amateur television culture, though the presence of web-based video exchange services (such as YouTube) is currently developing such opportunities in another medium. Instead of productions by sthe peoples, television has been interested in representations of sthe peopler, and academic discourses about British television have addressed this in relation to the criteria of Public Service Broadcasting. What is at stake are questions of equality (especially in gender, race and class) and the resonance between representations and perceived shifts in cultural politics. Each of these research problems contains an assumption that television could or should achieve a judicious and appropriate relationship with British society. While it would be naïve to expect television to accurately mirror society, concern about representation followed from similar preoccupations in radio and documentary cinema of the 1920s and 1930s, and when television increasingly took on the role of the primary mass broadcasting medium in the 1950s, those documentary assumptions moved into television. Developments in recording technology enabled television documentary makers to record sound synchronized with the image, and drew on the achievements of radio feature producers in basing programmes around interviews conducted on location, recording the ordinary speech of non-actors. In Britain, while the shaping of documentary programmes remained the province of directors and production teams distanced from their subject by their class status, expertise and membership of professional broadcasting institutions, the speech of ordinary people reflecting on their own experience and attitudes became an increasing feature of television factual programming. This notion of the access of ordinary people to the representations of their own lives has become progressively more significant in television documentary and in factual entertainment genres. It has been considered broadly as a preoccupation with testimony. Bearing witness to a person's own life experience, speaking as oneself, and individuating a notion of the ordinary, are how representations of the people s on television have been analysed (Dovey 2000).

In British television, the producers of the BBC series Video Nation, for example, were keen to bring to television the heritage of the 1930s Mass Observation project, which collected the comments and personal accounts of a large number of people who kept diaries of their everyday lives and commented on the social and political events of the time. In the last twenty years, in Video Diaries and many other programmes featuring ordinary people, the video diary format has been introduced as a component of both conventional documentary (where both the subjects of the programme and also its makers might produce video diary recordings) and also of created reality TV formats (like Big Brother and its diary room). Participants speak 
privately to camera about themselves, knowing that this private speech will become public when the programme is broadcast. Theoretical discourses addressing television have therefore analysed how, in recent factual programmes, the boundaries between private and public are blurred by the video confessional. Furthermore, the notion of the makeover, and the ideology of self-improvement, have been argued to be implicit in reality TV formats (Piper 2004). While some residue of the aim of earlier documentary forms to place their projects within a social dimension remains, reality TV blurs the distinction between private and public, and the relationships between a personal experience that might reveal something about an individual and a more broadly conceived public world involving work, institutions or communities. The diagnosis of recent television shows how the ordinary self is understood as mutable and improvable, as well as expressible, and contributes to a wider analysis of the privatization and commodification of experience.

The special circumstances of the staged factual series are designed to develop this to an extreme degree, and to focus it on the body and ethics of bodily exchange. A whole literature developed to analyse Big Brother in these terms in the early 2000s (Mathijs/Jones 2004). The transnational circulation of this combination of the private body and self, and public and communal ethical challenges and tests, has also been analysed as an economic activity. The television formats involved are traded goods and the attraction of audiences supports the channels that broadcast programmes in a variety of ways (through advertising, sponsorship, or brand extensions into spin-off consumer products, for example). Youth audiences have been addressed by this combination of elements because they watch relatively little television but are very valuable to advertisers because of their disposable income. Big Brother was designed to be successful with this audience, and proved to be so in many of the television cultures around the world in which it was shown. For example, Big Brother Africa ran for 106 days and was broadcast across Africa to 40 countries in 2003, and the differences of reception of the same format in different geographical contexts became an important aspect of the scholarship about the Big Brother phenomenon.

In relation to the conception of the popular as a question of representation, it is interesting to consider in what ways Big Brother Africa was 'popular (Bignell 2005, 34-38). The possibility that the series represented African unity and produced a sense of shared identity is complicated by the fact that it was accessible primarily to English-speaking Africans. Its audiences consisted not only of individual viewers but also of communal groups watching in bars or in the homes of the 4 percent of the continent's population who own television sets. The programme types attracting those wealthy enough to subscribe to the M-Net network's satellite transmissions consist of formats familiar to audiences in the developed world, such as soap operas, football and African versions of reality TV series. It seems likely that for Africans the appeal of this kind of programme mix, and of Big Brother in particular, was that it represented an African-originated programme whose 
focus was not on the international news agenda's usual list of representations of the continent, which centres on war and natural disasters. Because of African nations' underfunded domestic production base, programming has consisted largely of imported Western and mainly American content, but Big Brother Africa included contestants from many African nations, and began with an equal number of male and female contestants. As in other versions worldwide, the housemates subsequently secured contracts as endorsers of products in advertising, as actors and as television presenters.

But among the political elites of some African countries, Big Brother Africa raised moral and political questions. The parliament in Malawi banned the series for two weeks until the high court declared this unconstitutional and required the national broadcaster to carry it again. President Sam Nujoma of Namibia asked the stateowned Namibian Broadcasting Corporation to cease broadcasting the programme, though Namibian audiences were largely heedless of his intervention. In Uganda, religious and women's groups, members of parliament and commentators denounced the series for immorality but it continued to be shown. Similarly in Zambia, Big Brother Africa was declared immoral by a pressure-group of Zambian churches, though they failed in their attempt to have it taken off air. The Nigerian media regulator sought legal grounds for prosecuting the channels broadcasting Big Brother Africa but failed to pursue a case successfully. The attempts at intervention arose because of what was perceived as non-African, Western immorality among the contestants, and Big Brother Africa demonstrated the shared standards of personal ethics prevalent among younger educated Africans from the participating nations, thus drawing public attention to generational differences between straditional and liberal social groups, and the impact of Western culture across the continent. Thus Big Brother Africa demonstrated the hybridity of contemporary African culture, both in terms of the mixing of different national contestants and the use of the Western format made specific to its region of broadcast. Reality TV claimed itself as a public space in which these homogeneities and differences could be played out for a large spopular audience, at the same time as political representatives who criticised the programme claimed also to speak for the peoples too. Popular programmes and genres function not only as consensual or hegemonic meeting-points for cultural forces, but also sites of dynamic contestation over what and for whom the popular may be.

\section{Critical Discourse from Authorship to Audience}

Academic work on television fiction in the UK began by centring on a social realist aesthetic, and valued formal complexity, reflexivity, the importance of authorship, and an engagement with contemporary issues. Canonical status has been attributed to adaptations of ‘classic literature and theatre, or programmes that have assimi- 
lated the related value given to authorship in the prestige television play or authored serial (Bignell 2007). So the canon is slanted towards drama that claims political engagement or aesthetic innovation. With some exceptions, this association has taken place around high-profile prime-time programmes that are peripheral to the generic closure supposed to delimit series and serial drama in the popular genres of fantasy or comedy, for example. But the mutual definition of the canonical and the popular against each other produces an illusory boundary. There are programmes that transgress this boundary, as the discussion of the US police drama CSI will demonstrate below. On one hand, critical discourses have a heritage of interest in the social-realist single television play, a concern for nationally-specific themes, settings and topics in documentary, and the valuation of authorship. On the other hand, more recently emergent pressures have redirected the impetus of pedagogy and critical publication. These include an interest in the popular, the acceptance of the significance of imported and especially US programmes to British television, and the development of critical discourses that investigate genres rather than single programmes. In addition, academic interest in audience responses rather than textual aesthetics, and the waning of the assumption by the political Left that progressive texts produce progressive viewers, also led to instability in the ways that popular television is defined and discussed.

Early work in the field (e.g., Brandt 1981) engaged with television drama through authorship, because methodologies for discriminating quality, political effectivity and formal innovation could be exemplified in the single television play and the prime-time high-profile television serial, forms which already privileged authorship as both a differentiating brand and a guarantor of quality for broadcasters and reviewers. Academic studies legitimated their criteria for selection by drawing on criteria already dominant in the study of literature and theatre drama, such as complexity, social engagement, originality or ambiguity. Unsurprisingly, the resulting selection of programmes consisted of dramas by established male writers of serious television plays or serials. But by 1990, a study by John Tulloch combined work on authorially branded television drama with empirical research on Australian viewers of the popular drama series The Flying Doctors (1986-1991) and explicitly contested the canon. Tulloch's work questioned the hierarchisation of drama into the sserious and 'popular and signalled an interest in reception that became increasingly important to studies taking their methodological bearings from sociology and anthropology as much as from literary traditions. An implicit and sometimes explicit discrimination of quality in programmes was replaced by critical discourses that used programmes as locations for considering the competing claims of authorship, genre, institution and reception in determining cultural meanings.

The research questions in studies of television drama began to focus on genres such as sitcom and soap opera, as well as authors (Brandt 1993). Generic programmes were implicitly canonised by their selection as examples of how rgood 
television opened up the multiple significations of apparently conventional forms. This connected earlier criteria for quality with the new valuation of popular television as potentially resistant as well as hegemonic. By this point, the disputes about canonicity in television drama and the legitimation of canons by critical concepts such as authorship, genre or ideological stance had become sufficiently insistent and clear that Charlotte Brunsdon (1998) could undertake an important metacritical analysis of academic publishing on this subject. Academic work by Robin Nelson (1997), for example, demonstrated how critical emphases on authorship, the single play, and a lament for a lost 'golden age of television drama missed out on the increasing predominance of popular series and also failed to account for audience response, the importance of genre as an organising principle, and postmodern questioning of evaluative methodologies of all kinds. Nelson's examples shifted the terrain of debate by including US drama series like NYPD Blue (1983-2005) along with the BBC's critical realist serial Our Friends in the North (1996). The reevaluation of past drama in terms of more current methodologies, and the re-evaluation of past methodologies in relation to current programmes, motivated a collection of essays by television writers, producers and academics that I collaborated on (Bignell et al. 2000). Around the turn of the century, publication on British television drama historicised itself and its canons, and in 2000 John Caughie's work on aesthetic debates around naturalism, modernism, realism and authorship returned to sserious drama. He historicised discourses of seriousness and quality, and located them in specific cultural debates. For different reasons, studies of television drama were being written with much greater reflexivity and were engaging with the question of the popular.

Some academic work has historicised the conception of the popular as a relational construct developing alongside shifting conceptions of quality (Bignell/Lacey 2005), but studies of popular television drama that address the histories of aesthetic forms have been restricted to analyses of programmes in genres and forms that allow for the rediscovery of unconventional expressive techniques rather than the historicisation of relatively conventional ones. But this problem for the field has been redressed to some extent by the phenomenon of academic publications addressing mixed readerships that include television fans and general readers. Some examples include books by Toby Miller (1997), Chris Gregory (1997), James Chapman (2002) and my collaboration with Andrew O'Day (2004). These are books about widely-known programmes in the fantasy, action and science fiction genres, and they have sidestepped the economic restrictions on commercial academic publishing, reinflecting the canon inasmuch as it is opened up to the programmes that become the subjects of academic studies. The distinctions between sserious drama and generic popular forms are artificially created by the processes of historiography and canonization, and parallel the deconstruction of that opposition in the deconstruction of the opposition between categories of reader. Opportunities for new scholarship have emerged as a result of this happy conjunction between different 
readerships and the different agendas of television historians and television enthusiasts.

The canon has partial stability and identity inasmuch as it is a locus of pedagogical activity. Until the early 1980s and the spread of the domestic videocassette recorder, there was no ready means for non-professionals to record or play back television programmes. Early academic work on television series discusses them as industrial rather than aesthetic objects of study precisely because of a lack of access to the programme for repeat viewing. To analyse the aesthetics of programmes, by addressing their visual and aural components, narrative form and generic characteristics, it was often necessary to describe shots and sequences in detail. As well as generating lengthy passages of information, the translation of these issues into written language necessarily segues from description to interpretation. An alternative to this activity, or a supplement to it, was the occasional use of sequences of still images reproduced in the text. A third alternative was to write or teach about television drama by referring to a written script, but this reinforced the focus of analysis on the authorial contribution of the writer. With the arrival of videotape for recording current programmes, and subsequently the retail sale of videotapes of a small selection of earlier programmes, the emphases of the field were transformed, and questions of visual style, performance and relationships between image and sound could be closely investigated.

In the teaching of television studies at university level, introductory books that bridge the teaching of professional competencies and critical methodologies are understandably concerned largely with the present and the immediate future, and with popular programmes. Course texts surveying critical approaches and discussing a wide range of genres, usually with a strongly contemporary rather than historical focus, are increasingly used to introduce the study of television. Since the majority of students using books as part of courses are likely to be between 17 and 25 years of age, programme examples discussed tend to be chosen from the decade preceding the book's publication. Older programmes tend to be those that have been discussed before, thus reinforcing canonicity by summarizing, questioning or developing what are considered to be key insights by earlier academics. Interacting with this is a tendency to discuss examples that are likely to have been collected, made available for retail, or are being repeated because of their continuing popularity. Keith Selby and Ron Cowdery's student text (1995) for instance, uses case studies of the soap opera Neighbours and the readily-available and canonised sitcom Fawlty Towers, made by and starring the former Monty Python performer John Cleese. The academic canon is closely associated with (though not identical to) the popular programmes and genres given priority by the political economy of retail marketing of television programmes and the publishers of studies of television. 


\section{Quality and Aesthetics}

While academic work has largely eschewed the making of distinctions that value one programme or genre over another, informal discourse about television and television drama in particular very often consists in identifying a good programme (or channel, or viewing experience). Methodologies deriving from literary and film studies have historically been adapted for the study of television programmes, and their focus on the construction of meaning and the aesthetic resources of the channels of communication in image and sound produce dominant expectations of what the study of popular television will prioritise. Studies of television are often concerned to identify features that make a programme aesthetically significant, such as visual textures, performers, or its legacy as the inspiration for subsequent programmes. Writing and teaching seek out programmes that represent resistant political identities, in their gender politics or their form, for example, or because an attention to popular culture is argued to be radical in itself. For example, academic analysis of the $1960 \mathrm{~s}$ British adventure series The Avengers centres largely on its later episodes in which colour film and larger budgets produced an emphasis on a camp mode of performance, and a visual style that borrowed from the emergent pop-art aesthetic of the period which had made a significant impact on commercial culture in fashion, advertising imagery and elsewhere. David Buxton (1990) argued that The Avengers represented a "pop" series in which style predominates over content, making a distinction between this and another category of the popular television series, the "human nature« series, in which problems are referred back to psychological and existential issues. This argument adopts The Avengers to represent the genre of the law-enforcement series, inflected with other generic components such as spy drama and fantasy, and links the programme's textual aesthetic to a socio-cultural context that can also allow meditation on gender representation, medium-specificity, intertextuality and intermediality. The Avengers becomes important partly for its own sake as an unusual and interesting manipulation of these television codes and conventions, but also as an example of a generic type, a historical period in popular culture, and a point of departure for theorisation of aesthetic reflexivity.

The critical evaluation of quality in television depends on attributing value either by claiming that a programme matches the medium's capabilities, or because bringing into television an aesthetic from outside it redresses an inherent predisposition for the medium to be of low quality. The US television theorist Horace Newcombe (1974) argued that the primary attributes of broadcast television are intimacy, continuity and immediacy, and thus that the medium is most suited to working on contemporary social anxieties through narrative forms characterised by verisimilitude and involvement with character and story. He associated visual stylishness, on the other hand, with cinema rather than television. In the British and US contexts at least, television has been considered a writer's medium, setting up an op- 
position between television as an aesthetically conservative medium of dialogue and character and cinema as more adventurous in style and narrative form. As contemporary Hollywood cinema has invested in films that base their appeal on spectacle, effects and distinctive directorial intervention in mise-en-scene, this supposed distinction between television and film has gained greater purchase (McLoone 1997). The result has been a relative neglect of television style, especially where style is significant to popular and generic programmes. Furthermore, the interest in British academic work on forms of television realism has focused attention on the cultivation of a style that effaces itself in order to witness character and environment rather than to draw attention to the mediation of narrative by specific audio-visual forms.

Theories of television viewership interact with these conceptions of the specificity of the medium. The viewer has been conceptualised as someone "casting a lazy eye over the proceedings, keeping an eye on events, or, as the slightly archaic designation had it, looking in « (Ellis 1982, 137). If audiences watch sporadically, inattentively and continually then complexity, ambiguity and other highly valued aesthetic qualities would be wasted on them. However, contemporary US drama series have adopted self-conscious stylishness as a key component of their form and appeal to audiences (McCabe/Akass 2007). Changes in institutional and technological contexts provided the conditions for this change in the aesthetics of popular generic programmes. Developing a distinctive aesthetic was not very significant in the USA's period of network dominance and the policy of /least objectionable programming ‘ when three US networks provided a restricted diet of programming for mass audiences, the kind of programmes that are definitively spopular،. But from the 1980 s onwards the emergence of cable channels (especially HBO) challenged network dominance and a culture of programmes for niche audiences, designed to reward repeated viewing, and supported by programme-related merchandise (especially retail videotape and DVD versions) came about (Curtin 2003). The phenomenon was mainly dependent on long-running drama series, such as Hill Street Blues and ER (Thompson 1997). As work by Simon Frith (2000) and Jane Feuer (2003) showed, discussing UK and US television respectively, contemporary quality television is simultaneously defined in relation to its aesthetics, mode of production and audiences. Quality television drama means an aesthetically ambitious programme type with the literary values of creative imagination, authenticity and relevance. As a mode of production, it is where writing and mise-en-scene are prioritised. Quality television is also valuable television in that it is what valuable viewers (relatively wealthy and educated social groups) enjoy and what they will pay for through subscription to paid channels. Popular genres such as police and hospital drama, or comedy series, claim the designation >quality،.

This questions the continued purchase of the concepts of the glance for describing television viewership, since attentiveness is both invited and rewarded by these programmes. It also questions the usefulness of the concept of flow in describing television's temporality, for flow refers both to the continuous broadcast of pro- 
grammes one after another (often interrupted by commercials and trailers) and also to the viewing experience as one of interrupted sequence. Popular programmes that foreground aesthetic style and narrative complexity implicitly attempt to stand outside of flow, and are marketed with such designations as sappointment television or 'must-see TV $\mathrm{r}$ that draw attention to this claim. The entire cable channel, $\mathrm{HBO}$, for example, marketed itself with the slogan "it's not TV, it's $\mathrm{HBO}$ «, which among other meanings refers to programmes' innovative use of visual brands or signature styles in distinction to the supposed homogeneity of earlier phases of television. Popular US series are shot on film, following the long history of series production for television based in Hollywood and using the resources of studios and personnel originally established for cinema production. While made for television, the emphasis on mise-en-scene associated with the greater depth of colour, contrastive lighting and more elaborate camera movement of production on film is responsible for much of the aesthetic quality attributed to these programmes. By shooting using single cameras, with film stock used for both interior and exterior sequences, planned and consistent visual signatures are made possible, and thus programme brands are created as much by visual style as by narrative and continuities of settings and characters. In series where visual style is offered as one of the principal attractions of the programme, however, the directorial contribution within the established aesthetic offers series producers opportunities to exploit auteurism at the same time as an established stylistic brand. When the film director Quentin Tarantino wrote and directed the final episode of CSP s fifth season in 2005, the episode garnered an audience in the USA of 30 million (McLean 2005), encouraging the identification of a directorial signature by including sequences of body trauma that reference both his film work and also the established series trademarks of visceral sequences of bodily injury.

Those US series considered quality television work with an economy comprising generic verisimilitude's adaptation of programmes to audience expectation, and also play with verisimilitude and genre by means of visual pleasure and spectacle. A reflexive awareness that these programmes are television is crucial to their play with contrasts between excessive or unconventional mise-en-scene and generic narrative, characterization and dialogue. They are series television but cinematically rich in visual terms. They are writer-producer led but exploit directorial control over camerawork and shot composition. They establish the specificities of US settings and use the resources of Hollywood's filmed television production system but are also recognised by British audiences, critics and broadcasters as quality television. These arguments have been made about the series CSI: Crime Scene Investigation for example, which features a forensic team who examine evidence from Las Vegas homicides and fatal accidents (Rixon 2006; Bignell 2009). The mantle of quality police drama has been inherited by CSI, which has been the tentpole programme in the CBS network's Thursday schedule, the most significant weekday evening. In its second year (2001-2002), CSI achieved the second-best ratings of any programme 
and in the following year was top-rated. By the fifth series in 2005, the franchise had spawned the spin-off series CSI: Miami and CSI: New York, the former of which, as noted above, was the most watched programme in the world in that year. The original CSI continues to be shown in syndication in the USA and sold to overseas broadcasters, and contributed significantly to the profile and audiences for Channel Five in the UK, for example. Shown in evening prime-time as part of a strip of acquired US police series, the CSI franchise contributed to Five's repositioning in the mid-2000s. The channel had attempted to peel away mass audiences from Britain's main commercial terrestrial broadcaster ITV by offering sports coverage, erotica and reruns of US films. But Five subsequently sought a reputation for quality by changing its mix of genres in evening programming, and heavily marketed a small group of acquired US programmes. The naming of this strip of programmes as "America's Finest" referenced not only the slang designation of the police force, but also the claim that these programmes represented the highest quality primetime imports. Quality and the popular worked together, and a British television institution defined its identity by prioritising imported US programmes.

It is certainly useful to demonstrate through work on examples such as CSI that the binary opposition between >quality and the popular is an illusory one, which confuses an aesthetic discourse with a political discourse. But as John Corner (1998, 135-146) has shown, the discrimination of what is of high quality has been elided with a desire to demonstrate and critique unequal access to those valued cultural products. One symptom of this confusion is the reluctance in academic studies of television to make judgments that value one programme or genre over another, and instead to imply political solidarity with , the people by describing how cultural meaning is produced in programmes that have numerically large audiences. Studies of audience responses to programmes, conducted by adopting ethnographic, anthropological methodologies, implicitly accept that the popular is defined by the consumer choices that viewers make, and attempt to describe and affirm popular experience rather than deconstructing it. The valuation of the popular, as both a category of programmes and a relative measure of audience size and composition, has diminished the confidence to adopt a discourse of ideology critique that values some programmes while dismissing others. Just as the meanings of , the popular s are multiple and contested in the television culture and in academic discourses, the evaluative significance of the term has divergent and sometimes problematic implications.

Jonathan Bignell

Department of Film, Theatre and Television

University of Reading 


\section{References}

Barker, Chris, Television, Globalization and Cultural Identities, Buckingham 1999.

BBC, Producer's Guidelines, London 2003.

Bignell, Jonathan, Big Brother: Reality TV in the $21^{\text {st }}$ Century, Basingstoke 2005.

-, Citing the Classics: Constructing British Television Drama History in Publishing and Pedagogy, in: Helen Wheatley (ed.), Re-viewing Television History: Critical Issues in Television Historiography, London 2007, 27-39.

-, The Police Series, in: John Gibbs/Douglas Pye (ed.), Close Up 03, London 2009, 1-66. Bignell, Jonathan/Andreas Fickers, Introduction: Comparative European Perspectives on Television History, in: J.B./A.F. (ed.), A European Television History, New York 2008, 1-54.

Bignell, Jonathan/Stephen Lacey/Madeleine Macmurraugh-Kavanagh (ed.), British Television Drama: Past, Present and Future, Basingstoke 2000.

Bignell, Jonathan/Stephen Lacey (ed.), Popular Television Drama: Critical Perspectives, Manchester 2005.

Bignell, Jonathan/Andrew O’Day, Terry Nation, Manchester 2004.

Brandt, George (ed.), British Television Drama, Cambridge 1981.

- (ed.), British Television Drama in the 1980s, Cambridge 1993.

Brunsdon, Charlotte, What is the Television of Television Studies?, in: Christine Geraghty/ David Lusted (ed.), The Television Studies Book, London 1998, 95-113.

-, The Feminist, the Housewife and the Soap Opera, London, 2000.

-, Is Television Studies History?, Cinema Journal 47:3 (2008), 127-137.

Brunsdon, Charlotte/Julie D’Acci/Lynn Spigel (ed.), Feminist Television Criticism: A Reader, Oxford 1997.

Buxton, David, From The Avengers to Miami Vice: Form and Ideology in Television Series, Manchester 1990.

Caughie, John, Television Drama: Realism, Modernism, and British Culture, Oxford 2000. Chapman, James, Saints \& Avengers: British Adventure Series of the 1960s, London 2002. Corner, John, Studying Media: Problems of Theory and Method, Edinburgh 1998.

Curtin, Michael, From Network to Neo-network Audiences, in: Michele Hilmes (ed.), The Television History Book, London 2003, 122-125.

De Bens, Els/Hedwig de Smaele, The Inflow of American Television Fiction on European Broadcasting Channels Revisited, European Journal of Communication 16:1 (2001), $51-76$.

Dovey, Jon, Freakshow: First Person Media and Factual Television, London 2000.

Dyer, Richard, Light Entertainment, London 1973.

Eden, Jenny, Caruso Control, Radio Times 5-11 August 2006, 11-12.

Ellis, John, Visible Fictions: Cinema, Television, Video, London 1982.

Feuer, Jane, Quality Drama in the US: The New »Golden Age«?, in: Michele Hilmes (ed.), The Television History Book, London 2003, 98-102.

Frith, Simon, The Black Box: The Value of Television and the Future of Television Research, Screen 41:1 (2000), 33-50.

Gregory, Chris, Be Seeing You...: Decoding the Prisoner, Luton 1997.

Gripsrud, Jostein, Television, Broadcasting, Flow: Key Metaphors in TV Theory, in: Christine Geraghty/David Lusted (ed.), The Television Studies Book, London 1997, 17-32. 
Mathijs, Ernest/Janet Jones (ed.), Big Brother International: Formats, Critics and Publics, London 2004.

McCabe Janet/Kim Akass (ed.), Quality TV: Contemporary American Television and Beyond, London 2007.

McLean, Gareth, CSI: Tarantino, The Guardian New Media, 11 July 2005, 12.

McLoone, Martin, Boxed In?: The Aesthetics of Film and Television, in: John Hill/Martin McLoone (ed.), Big Picture, Small Screen: The Relations between Film and Television, Luton 1997, 76-106.

Miller, Toby, The Avengers, London 1997.

Nelson, Robin, TV Drama in Transition: Forms, Values and Cultural Change, Basingstoke 1997.

Newcombe, Horace, Television: The Most Popular Art, New York 1974.

Piper, Helen, Reality TV, Wife Swap and the drama of banality, Screen $45: 4$ (2004), 273-286.

Rixon, Paul, American Television on British Screens: A Story of Cultural Interaction, London 2006.

Schiller, Herbert, Mass Communications and American Empire, New York 1969.

-, Communication and Cultural Domination, New York 1976.

Selby, Keith/Ron Cowdery, How to Study Television, Basingstoke 1995.

Sinclair, John/Elizabeth Jacka/Stuart Cunningham, New Patterns in Global Television, in:

Paul Marris/Sue Thornham (ed.), The Media Reader, Edinburgh 1999, 170-190.

Thompson, Robert, Television's Second Golden Age: From Hill Street Blues to ER, Syracuse 1997.

Tulloch, John, Television Drama: Agency, Audience and Myth, London 1990.

Williams, Raymond, Television: Technology and Cultural Form, London 1974.

Television Programmes

Avengers, The (ATV, UK, 1961-69)

Big Brother (Endemol Entertainment, Netherlands, 1999-)

Big Brother Africa (Endemol Entertainment, South Africa, 2003-)

CSI: Crime Scene Investigation (Alliance Atlantis/CBS, USA, 2000-)

CSI: Miami (Alliance Atlantis/CBS, USA, 2007-)

CSI: New York (Alliance Atlantis/CBS, USA, 2004-)

Desperate Housewives (ABC, USA, 2004-)

ER (Warner Bros. Television, USA, 1994-2009)

Fawlty Towers (BBC, UK, 1975-1979)

Flying Doctors, The (Crawford Productions, Australia, 1986-1991)

Hill Street Blues (MTM Enterprises, USA, 1981-87)

Lost (ABC, USA, 2004-10)

Neighbours (Grundy Television, Australia, 1985-)

NYPD Blue (Steven Bochco Productions, USA, 1983-2005)

Our Friends in the North (BBC, UK, 1996)

Pop Idol (Thames Television, UK, 2001-2003)

Simpsons, The (Fox Broadcasting, USA, 1989-)

Strictly Come Dancing (BBC, UK, 2004-)

Video Diaries (BBC, UK, 1990-1993)

Video Nation (BBC, UK, 1993-)

Without a Trace (CBS, USA, 2002-2009) 